\title{
Persepsi Dukungan Sosial sebagai Mediator Pengungkapan Diri dan Kesejahteraan Subjektif pada Pengguna Instagram
}

\author{
Shabrina Nur Adzhani ${ }^{(1)}$, M.I.F. Baihaqi ${ }^{(2)}$, Engkos Kosasih ${ }^{(3)}$ \\ (1),(2),(3) Jurusan Psikologi, Universitas Pendidikan Indonesia, \\ Bandung, Indonesia
}

\begin{abstract}
This study aimed to examine the mediating role of the perceptions of social support on the relationship between self-disclosure and subjective well-being of Instagram users in Bandung. Participants were 466 late teenagers ranging from 18 to 21 years old. The research was conducted by utilizing Instagram, a social media platform, in Bandung City. The data were analysed quantitatively and demonstrated that: 1) self-disclosure had a significant influence towards respondents' subjective well-being, 2) self-disclosure had a significant influence towards perceived social support, 3) perceived social support had a significant influence towards respondents' subjective well-being, 4) perceived social support significantly mediated the relationship between self-disclosure and subjective well-being.
\end{abstract}

Keywords: Instagram users, perceived social support, self-disclosure; subjective well-being

Penelitian ini bertujuan untuk mengetahui peran persepsi dukungan sosial sebagai mediator hubungan antara pengungkapan diri dan kesejahteraan subjektif pada pengguna Instagram di Kota Bandung. Subjek penelitian terdiri dari 466 remaja akhir yang berusia 18 hingga 21 tahun yang menggunakan media sosial Instagram di Kota Bandung. Data dalam penelitian ini dianalisis secara kuantitatif dan menunjukkan bahwa: 1) pengungkapan diri berpengaruh secara signifikan terhadap kesejahteraan subjektif, 2) pengungkapan diri berpengaruh secara signifikan terhadap persepsi dukungan sosial, 3) persepsi dukungan sosial berpengaruh secara signifikan terhadap kesejahteraan subjektif, 4) persepsi dukungan sosial secara signifikan menjadi variabel mediator bagi peran pengungkapan diri terhadap kesejahteraan subjektif.

Kata kunci: kesejahteraan subjektif, pengguna Instagram, pengungkapan diri, persepsi dukungan sosial

MEDIAPSI, 2020, Vol. 6(1), 60-70, DOI: https://doi.org/10.21776/ub.mps.2020.006.01.7

Received: 10-12-2019. Revised: 04-04-2020. Accepted: 30-04-2020. Published online: 12-06-2020

Handling Editor: Sumi Lestari, Universitas Brawijaya, Malang, Indonesia

*Corresponding author: Shabrina Nur Adzhani, Jurusan Psikologi, Universitas Pendidikan Indonesia, Bandung, Indonesia. E-mail: : shabrinanuradzhani@gmail.com

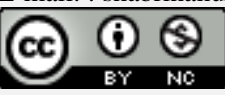

This work is licensed under a Creative Commons Attribution-NonCommercial 4.0 International License.

How to cite this article in accordance with the American Psychological Association (APA) $6^{\text {th }}$ guidelines:

Adzhani, S. N., Baihaqi, M. I. F., \& Kosasih, E. (2020). Persepsi dukungan sosial sebagai mediator pengungkapan diri dan kesejahteraan subjektif pada pengguna instagram. MEDIAPSI, 6(1), 60-70. https://doi.org/10.21776/ub.mps.2020.006.01.7

\section{Pendahuluan}

Media sosial memberikan berbagai macam kemudahan dalam menunjang kehidupan sehari-hari. Individu dapat menggunakan media sosial untuk berkomunikasi dengan orang lain melalui media sosial secara efisien tanpa batasan waktu dan lokasi (Lee, Lee, \& Kwon, 2011). Data yang didapat dari Asosiasi Penyelenggara Jasa Internet Indonesia (2017) menunjukkan bahwa di Indonesia, persentase penggunaan media mencapai $87.13 \%$. Hal ini menjadikan media sosial nenempati peringkat 
kedua dalam hal akses internet di kalangan masyarakat Indonesia. Berdasarkan usia pengguna internet, usia 13-18 tahun berada ditingkat pertama dengan persentase $75.50 \%$ dan usia 19-34 tahun berada di tingkat kedua dengan persentase $74.23 \%$. Berdasarkan data tersebut, pengguna media sosial di Indonesia didominasi oleh usia remaja.

Penggunaan media sosial dinilai sangat mampu memengaruhi kesejahteraan subjektif para remaja. Kesejahteraan subjektif merupakan penilaian individu mengenai kebahagiaan dan kepuasan dalam hidup (Diener, Oishi \& Lucas, 2003). Hasil penelitian yang dilakukan oleh Valkenburg, Peter, dan Schouten (2006) menunjukkan bahwa frekuensi penggunaan media sosial bernama See You Too di Belanda memiliki pengaruh secara tidak langsung pada kesejahteraan remaja. Hal tersebut disebabkan karena remaja mendapatkan tanggapan positif yang meningkatkan kesejahteraan remaja melalui media sosial. Pengguna blog di Taiwan pun menunjukkan sebuah peningkatan kesejahteraan subjektif yang disebabkan oleh kepuasan dalam melakukan kontak sosial dan komunikasi interpersonal melalui blog (Ko \& Kou, 2009).

Kesejahteraan subjektif penting untuk dimiliki oleh remaja yang sedang berada dalam tahap perkembangan. Alasannya adalah salah satu komponen dari kesejahteraan subjektif, yaitu kepuasan hidup, dapat melindungi remaja dari berbagai masalah psikologis dan perilaku dalam menghadapi tekanan lingkungan (Park, 2004). Kesejahteraan subjektif penting untuk dimiliki individu karena mampu menjadi pencegah munculnya depresi, meningkatkan kepuasan hidup, membantu proses pembelajaran yang lebih baik, dan meningkatkan pemikiran yang jauh lebih kreatif (Seligman, 2013). Kesejahteraan subjektif cenderung membantu individu untuk berfungsi lebih baik (Neve, Diener, Tay \& Xuereb, 2013).

Selain mampu memengaruhi kualitas kesejahteraan subjektif remaja, media sosial memberikan kemudahan dalam hal pengungkapan diri atau penyampaian informasi mengenai diri sendiri kepada orang lain. Awalnya remaja lebih sering mengungkapkan diri kepada teman sebayanya melalui komunikasi tatap muka (Valkenburg \& Peter, 2011). Saat ini remaja dapat mengungkapkan diri kepada orang lain melalui media sosial (Chen, Zhou, Zhu, \& Xu, 2012). Hal tersebut menyebabkan peningkatan kebutuhan untuk mengungkapkan informasi mengenai diri sendiri secara online (Taddei \& Contena, 2013). Pengungkapan diri melalui media sosial pun memiliki hubungan positif dengan kesejahteraan subjektif. Hal tersebut disebabkan pengguna media sosial bisa mendapatkan informasi timbal balik dan dukungan sosial dari orang lain (Lee dkk., 2011).

Media sosial juga memberikan peluang kepada penggunanya untuk saling berinteraksi dan memberikan dukungan. Saat individu merasa kesepian lalu membagikan informasi mengenai diri sendiri melalui media sosial, individu tersebut akan memiliki kesempatan untuk mendapatkan dukungan sosial yang dapat memengaruhi kesejahteraan subjektif. Dukungan sosial yang didapatkan bisa dalam bentuk respon ketika individu membagikan informasi mengenai perasaannya (Lee, Noh, \& Koo, 2013). Menurut Chu, Saucier, dan Hafner (2010), persepsi dukungan sosial atau keyakinan individu mengenai tersedianya dukungan sosial dinilai lebih baik untuk melihat keadaan psikologis seseorang dibandingkan dengan dukungan sosial yang didapatkan. Hal tersebut disebabkan karena dukungan sosial yang terlalu banyak didapatkan tetapi tidak terlalu dibutuhkan justru dapat memperburuk stres (Taylor dkk., 2004).

Informasi dari pengungkapan diri yang dibagikan melalui media sosial dapat berupa pikiran, perasaan, dan pengalaman (Wang, Zhang, Chen, \& Zeng, 2018). Pengungkapan 
diri sendiri melalui media sosial memberikan berbagai dampak positif seperti dapat membantu pengguna media sosial untuk memahami pengalaman yang bersifat menyedihkan, mampu mendapatkan penerimaan dari orang lain, serta mendapatkan dukungan sosial (Ko \& Kou, 2009; Tichon \& Saphiro, 2003).

Pengungkapan diri memiliki hubungan yang positif dengan persepsi dukungan sosial. Individu yang memiliki kemampuan untuk mengungkapkan diri biasanya dapat membentuk hubungan jangka panjang yang baik dan memiliki jaringan sosial yang luas sehingga akan lebih memiliki persepsi tentang ketersediaan dukungan sosial pada saat dibutuhkan (Batool \& Zubair, 2018). Individu yang lebih jujur dalam membagikan informasi mengenai dirinya di media sosial pun akan lebih memiliki persepsi ketersediaan dukungan sosial dan rasa kesepian akan semakin berkurang (Wei, Zou, \& Wang, 2018). Penelitian lain menunjukkan bahwa persepsi dukungan sosial dapat menjadi mediator antara jumlah teman di Facebook dengan kesejahteraan subjektif. Hal tersebut disebabkan karena semakin besar jumlah teman yang terhubung akan memberikan peluang kepada individu untuk memiliki keyakinan dalam mendapatkan dukungan sosial yang akan meningkatkan kesejahteraan subjektif (Nabi, Prestin, \& So, 2013).

Peneliti telah melakukan studi pendahuluan melalui kuesioner online pada 109 remaja di Kota Bandung, dengan rincian responden berjenis kelamin laki-laki sebanyak 17 dan responden perempuan sebanyak 92. Data studi pendahuluan tersebut menunjukkan bahwa media sosial yang digunakan oleh responden untuk membagikan informasi mengenai diri sendiri adalah Instagram dengan persentase sebesar $41.3 \%$, Line $26.6 \%$, Whatsapp $18.3 \%$, Twitter $8.3 \%$, dan Tumblr $2.1 \%$. Berdasarkan data tersebut Instagram adalah media sosial yang paling banyak digunakan oleh remaja untuk membagikan informasi mengenai dirinya sendiri. Selain itu, 23 responden berpendapat bahwa mereka merasa senang ketika menggunakan media sosial Instagram. Alasan yang diberikan oleh responden diantaranya adalah karena senang membagikan sesuatu seperti informasi yang bermanfaat kepada orang lain, mengisi waktu luang, menemukan berbagai hal yang disukai, mendapatkan inspirasi dan informasi, serta merasa senang ketika melihat kebahagiaan orang lain yang dibagikan melalui Instagram.

Hasil penelitian sebelumnya mengukur hubungan pengungkapan diri dengan dukungan sosial yang hanya didapatkan dari sesama pengguna media sosial. Peneliti tertarik menggunakan persepsi dukungan sosial sebagai konsep atau konstruk yang lebih sesuai untuk menilai kondisi psikologis serta melihat keyakinan individu mengenai dukungan sosial yang dirasakan saat dibutuhkan di dunia nyata. Selain itu, belum ada yang menggunakan media sosial Instagram untuk mengukur perilaku pengungkapan diri melalui media sosial dan pengaruhnya terhadap kesejahteraan subjektif. Peneliti berpandangan bahwa persepsi dukungan sosial yang bersifat virtual melalui media sosial bisa menjadi mediator hubungan antara pengungkapan diri dan kesejahteraan subjektif dibandingkan dengan persepsi dukungan sosial yang bersifat face-to-face. Berdasarkan hal itu, peneliti menjadikan gap tersebut sebagai tujuan dari penelitian ini.

Terdapat empat hipotesis dalam penelitian ini. Hipotesis pertama adalah pengungkapan diri memiliki pengaruh terhadap kesejahteraan subjektif (H1). Hipotesis kedua menyatakan bahwa pengungkapan diri memiliki pengaruh terhadap persepsi dukungan sosial (H2). Hipotesis yang ketiga adalah persepsi dukungan sosial memiliki pengaruh terhadap kesejahteraan subjektif (H3). Hipotesis keempat menyatakan bahwa persepsi dukungan sosial 
menjadi mediator antara pengungkapan diri dengan kesejahteraan subjektif yang dimiliki oleh pengguna Instagram di Kota Bandung (H4).

\section{Metode}

\section{Partisipan dan desain penelitian}

Populasi yang terlibat dalam penelitian ini adalah remaja akhir dengan rentang usia 18 hingga 21 tahun. Kriteria ini didasarkan pada kenyataan bahwa remaja cenderung lebih mudah untuk mengungkapkan informasi pribadi di media sosial daripada orang dewasa (Walrave, Vanwesenbeeck, \& Heriman, 2012). Selain itu, remaja juga sedang mengalami peningkatan keintiman dengan teman sebaya, yang menyebabkan terjadinya peningkatan pengungkapan diri remaja dengan teman sebaya (Buhrmester \& Prager, 1995).

Menurut Steinberg (2016), usia remaja dibagi menjadi tiga bagian, yaitu remaja awal (usia 10-13 tahun), remaja menengah (usia 1417 tahun), dan remaja akhir (usia 18-21 tahun). Informasi lain yang didapatkan dari Paul Webster yang merupakan seorang Brand Development Lead Instagram APAC menunjukkan bahwa mayoritas usia pengguna Instagram di Indonesia rata-rata berada pada usia 18-24 tahun dengan persentase sebesar 59\% (Mailanto, 2016). Mengacu pada temuan ini, peneliti menetapkan populasi penelitian adalah remaja laki-laki maupun perempuan dengan rentang usia 18 hingga 21 tahun yang menggunakan media sosial Instagram dan berdomisili di Kota Bandung.

Pengambilan sampel dalam penelitian ini menggunakan teknik nonprobability sampling dikarenakan peneliti memiliki kriteria khusus yang telah ditetapkan (Creswell, 2012). Jenis nonprobability sampling yang digunakan peneliti adalah convenienve sampling dimana peneliti memilih responden yang sesuai dengan kriteria dan bersedia untuk menjadi responden dalam penelitian.
Pendekatan yang digunakan dalam penelitian ini adalah kuantitatif dengan desain korelasional untuk mengetahui pengaruh pengungkapan diri $(\mathrm{X})$ terhadap kesejahteraan subjektif (Y) yang dimediasi oleh persepsi dukungan sosial $(\mathrm{Z})$ pada pengguna Instagram yang berdomisili di Kota Bandung. Secara lebih mendetail, karakteristik responden penelitian ditampilkan dalam Tabel 1 di bawah ini.

Tabel 1. Data Demografis Responden Penelitian

\begin{tabular}{lcc}
\hline Karakteristik & Frekuensi & Persentase \\
\hline Jenis Kelamin & & \\
Laki-Laki & 107 & $22.96 \%$ \\
Perempuan & 359 & $77.04 \%$ \\
Usia & & \\
18 tahun & 111 & $23.8 \%$ \\
19 tahun & 110 & $23.6 \%$ \\
20 tahun & 94 & $20.2 \%$ \\
21 tahun & 151 & $32.4 \%$ \\
Pendidikan & & \\
S1 & 440 & $94.4 \%$ \\
D4 & 4 & $0.9 \%$ \\
D3 & 14 & $3 \%$ \\
SMA & 8 & $1.7 \%$ \\
\hline
\end{tabular}

\section{Prosedur dan pengukuran}

Instrumen penelitian yang digunakan dalam penelitian ini terdiri dari tiga skala pengukuran. Instrumen yang digunakan untuk mengukur pengungkapan diri didasarkan pada Revised Self-Disclosure Scale (RSDS) yang dikembangkan oleh Wheeless (1978). Skala ini kemudian diadaptasi dalam penggunaan Instagram oleh Fauzia (2019) dengan realiabilitas sebesar $\alpha=0.85$. Contoh aitem dalam instrumen ini yaitu "saya selalu jujur dalam menceritakan diri saya di instagram" dan "saya sering mengunggah insta stories tentang kegiatan sehari-hari." Pengisian kuesioner pengungkapan diri dilakukan oleh responden dengan memilih dan memberikan tanda ceklis pada salah satu skala dari empat pilihan skala, yaitu dengan rentang pilihan 1 (Sangat Tidak Setuju) sampai dengan 4 (Sangat Setuju).

Instrumen yang digunakan untuk 
mengukur persepsi dukungan sosial adalah Multidimensional Scale of Perceived Social Support (MSPSS) yang dikembangkan oleh Zimet, Dahlem, Zimet, dan Farley (1988). Instrumen ini membagi sumber dukungan sosial ke dalam tiga kategori, yaitu keluarga ( $\alpha=$ $0.87)$, teman $(\alpha=0.85)$, dan significant others $(\alpha=0.91)$. Sementara itu, reliabilitas untuk keseluruhan instrumen ini adalah $\alpha=0.88$. Contoh aitem untuk sumber dukungan keluarga adalah "keluarga saya benar-benar berusaha untuk membantu saya" dan "teman-teman saya benar-benar berusaha untuk membantu saya." Pengisian kuesioner persepsi dukungan sosial dilakukan oleh respoden dengan memilih dan memberikan tanda ceklis pada salah satu dari tujuh pilihan skala, yang bervariasi dari 1 (Sangat Tidak Setuju) sampai dengan 7 (Sangat Setuju).

Instrumen yang digunakan untuk mengukur kesejahteraan sujektif terdiri dari dua instrumen, yaitu Satisfaction with Life Scale yang dirancang oleh Diener, Emmons, Larsen, dan Griffin (1985), yang mengukur penilaian kognitif secara keseluruhan mengenai kepuasan hidup seseorang $(\alpha=0.87)$. Contoh aitem instrumen ini adalah "dalam banyak hal, hidup saya sudah mendekati ideal" dan "keadaan hidup saya sangat baik." Instrumen kedua menggunakan Scale of Positive and Negative Experience (SPANE) yang dirancang oleh Diener dkk. (2009), yang mengukur afek positif dan negatif $(\alpha=0.89)$. Aitem instrumen ini meliputi nama-nama perasaan positif maupun negatif, seperti senang, sedih, nyaman, tidak nyaman. Pengisian kuesioner kesejahteraan subjektif pada alat ukur Satisfaction with Life dilakukan oleh responden dengan memilih dan memberikan tanda ceklis pada salah satu dari tujuh pilihan skala, yang merentang mulai dari 1 (Sangat Tidak Setuju) sampai dengan 7 (Sangat Setuju). Selain itu, pengisian pada alat ukur SPANE dilakukan oleh respoden dengan memilih dan memberikan tanda ceklis pada MEDIAPSI | 2020. Vol. 6, No. 1, 60-70 salah satu dari lima pilihan skala (yaitu: 1 [Sangat Jarang] sampai dengan 5 [Sangat Sering]).

\section{Teknik analisis data}

Teknik analisis data yang digunakan dalam penelitian ini adalah analisis regresi linier berganda untuk mengetahui pengaruh pengungkapan diri $(\mathrm{X})$ terhadap kesejahteraan subjektif (Y) yang dimediasi oleh persepsi dukungan sosial (Z). Sebelum melakukan uji regresi, peneliti melakukan transformasi data dari data ordinal menjadi interval menggunakan Rash model melalui aplikasi Winstep. Setelah data interval didapatkan, peneliti menggunakan aplikasi SPSS untuk analisis regresi linier sederhana maupun regresi linear berganda untuk menguji hipotesis penelitian. Analisis regresi berganda digunakan karena mampu menjelaskan hubungan ketiga variabel (Cresswell, 2012).

\section{Hasil}

Tabel 2 di bawah ini menunjukkan nilai $R$ sebesar 0.125 dan nilai signifikansi sebesar 0.007 sehingga dapat disimpulkan bahwa pengaruh pengungkapan diri terhadap kesejahteraan subjektif adalah sebesar 1.6\% ( $R$ square $\mathrm{x}$ 100). Berdasarkan hasil tersebut hipotesis pertama diterima.

Tabel 2. Hasil Analisis Regresi Sederhana Pengaruh Pengungkapan Diri Terhadap Kesejahteraan Subjektif

\begin{tabular}{|c|c|c|c|c|c|c|}
\hline Model & $B$ & Sig. & $R$ & $\begin{array}{c}R \\
\text { Square }\end{array}$ & $F$ & Sig. \\
\hline (constant) & 51.813 & 0.000 & & & & \\
\hline $\begin{array}{l}\text { Pengungkapan } \\
\text { Diri }\end{array}$ & 0.324 & 0.007 & 0.125 & 0.016 & 7.363 & 0.007 \\
\hline
\end{tabular}

Dependent variable: Kesejahteraan subjektif

Tabel 3. Analisis Regresi Linier Sederhana Pengaruh Pengungkapan Diri Terhadap Persepsi Dukungan Sosial

\begin{tabular}{lcccccc}
\multicolumn{1}{c}{ Model } & $B$ & Sig. & $R$ & $\begin{array}{c}R \\
\text { Square }\end{array}$ & $F$ & Sig. \\
\hline $\begin{array}{l}\text { (constant) } \\
\begin{array}{l}\text { Pengungkapan } \\
\text { Diri }\end{array}\end{array}$ & 11.687 & 0.000 & & & & \\
\hline \multicolumn{7}{l}{ Dependent variable: Persepsi dukungan sosial } \\
\end{tabular}


Tabel 3 menunjukkan nilai $R$ sebesar 0.092 dan nilai signifikansi sebesar $p=0.048$. Dengan hasil ini, bisa disimpulkan bahwa pengaruh variabel pengungkapan diri terhadap variabel persepsi dukungan sosial adalah sebesar $0.8 \%$ ( $R$ square $\mathrm{x} 100$ ). Berdasarkan hasil tersebut, hipotesis kedua diterima.

Tabel 4. Analisis Regresi Linier Sederhana Pengaruh Persepsi Dukungan Sosial Terhadap Kesejahteraan Subjektif

\begin{tabular}{|c|c|c|c|c|c|c|}
\hline Model & $B$ & Sig. & $R$ & $\begin{array}{c}R \\
\text { Square }\end{array}$ & $F$ & Sig. \\
\hline (constant) & 40.560 & 0.000 & & & & \\
\hline $\begin{array}{l}\text { Persepsi } \\
\text { dukungan } \\
\text { sosial }\end{array}$ & 0.865 & 0.000 & 0.503 & 0.253 & 156.998 & $\begin{array}{c}< \\
0.001\end{array}$ \\
\hline
\end{tabular}

Tabel 4 menunjukkan nilai $R$ sebesar 0.503 dan nilai signifikansi sebesar $p<0.001$. Hasil ini mengandung arti bahwa pengaruh persepsi dukungan sosial terhadap kesejahteraan subjektif adalah sebesar $25.3 \%(R$ square $\mathrm{x}$ 100). Berdasarkan hasil tersebut, hipotesis ketiga diterima.

Tabel 5. Hasil Analisis Regresi Berganda Pengaruh Pengungkapan Diri Terhadap Kesejahteraan Subjektif Dimediasi oleh Persepsi Dukungan Sosial.

\begin{tabular}{|c|c|c|c|c|c|c|}
\hline Model & B & Sig. & $R$ & $\begin{array}{c}R \\
\text { Square }\end{array}$ & $F$ & Sig. \\
\hline (constant) & 41.851 & 0.000 & \multirow[b]{3}{*}{0.509} & \multirow[b]{3}{*}{0.259} & \multirow[b]{3}{*}{80.958} & \multirow{3}{*}{$\begin{array}{c}< \\
0.001\end{array}$} \\
\hline $\begin{array}{l}\text { Pengungkapan } \\
\text { Diri }\end{array}$ & 0.206 & 0.048 & & & & \\
\hline $\begin{array}{l}\text { Persepsi } \\
\text { dukungan } \\
\text { sosial }\end{array}$ & 0.852 & 0.000 & & & & \\
\hline
\end{tabular}

Tabel 5 menunjukkan nilai $R$ sebesar 0.509 dan nilai signifikansi $\mathrm{p}<0.001$. Temuan ini bermakna bahwa pengaruh pengungkapan diri dan kontribusi persepsi dukungan sosial sebagai mediator terhadap kesejahteraan subjektif sebesar 25.9\%. Menurut Baron dan Kenny (1986), sebelum melakukan mediasi syarat-syarat berikut harus terpenuhi. Pertama, variabel independen $(\mathrm{X})$ menunjukkan pengaruh terhadap variabel dependen (Y).
Kedua, variabel independen (X) harus memengaruhi mediator (Z). Ketiga sekaligus terakhir, variabel mediator (Z) harus memengaruhi variabel dependen (Y). Jika syarat-syarat ini terpenuhi maka bisa ditarik kesimpulan bahwa pengaruh atau kontribusi variabel independen terhadap variabel dependen secara signifikan harus melewati variabel mediator.

Hasil perhitungan statistik menunjukkan bahwa koefisien regresi pengungkapan diri tanpa dimediasi oleh persepsi dukungan sosial yang ditunjukkan pada Tabel $2(B=0.324)$ lebih besar dibandingkan koefisien regresi pengungkapan diri yang dimediasi persepsi dukungan sosial pada Tabel $5(B=0.206)$. Artinya, koefisien regresi dalam penelitian ini mengalami penurunan. Berdasarkan hasil temuan tersebut, dapat disimpulkan bahwa persepsi dukungan sosial memediasi pengaruh pengungkapan diri terhadap kesejahteraan subjektif. Dengan hasil ini, hipotesis ketiga sekaligus hipotesis utama dalam penelitian ini diterima.

\section{Diskusi}

Penelitian ini menunjukkan hasil bahwa pengungkapan diri memiliki pengaruh terhadap kesejahteraan subjektif. Temuan ini sesuai dengan penelitian Lee dkk. (2011), yang menunjukkan bahwa interaksi yang terjadi di dunia nyata dapat dilakukan juga di media sosial, yang dapat memengaruhi modal sosial atau hubungan yang dijalani individu dengan adanya kepercayaan dan rasa saling pengertian. Lee dkk. (2013) juga mengungkapkan bahwa pengungkapan diri dinilai dapat mengurangi rasa kesepian dan dapat meningkatkan kesejahteraan subjektif dengan melibatkan peran dari dukungan sosial yang didapatkan dari media sosial. Berdasarkan hal tersebut, penelitian ini pun menunjukkan bahwa pengungkapan diri di media sosial dapat memengaruhi kesejahteraan subjektif individu 
karena pengguna media sosial memiliki kesempatan mendapatkan dukungan sosial di dunia nyata akibat interaksi yang dilakukan melalui media sosial.

Penelitian ini pun menunjukkan bahwa pengungkapan diri memiliki pengaruh terhadap persepsi dukungan sosial. Temuan ini sesuai dengan hasil penelitian yang dilakukan oleh Batool dan Zubair (2018), yang melaporkan adanya pengaruh pengungkapan diri terhadap dukungan sosial. Persepsi dukungan sosial atau keyakinan seseorang terhadap tersedianya dukungan ketika dibutuhkan dapat dimiliki jika individu mampu membentuk dan menjaga hubungan baik dengan orang lain, yang bisa direalisasikan salah satunya dengan memiliki kemampuan pengungkapan diri. Pengungkapan diri adalah salah satu cara yang dapat dilakukan untuk memperkuat rasa saling memiliki, meningkatkan keintiman, serta koneksi dengan orang lain (Ko \& Kou, 2009). Pengungkapan diri yang dilakukan secara jujur di media sosial akan lebih besar memberikan keyakinan mengenai persepsi dukungan sosial pada individu tersebut (Wei, Zou, \& Wang, 2018).

Sebagaimana telah dijelaskan sebelumnya, dukungan sosial yang didapatkan seseorang bisa bersumber dari keluarga, teman, serta orang yang dinilai dekat oleh individu (Yusoff, 2011). Penyampaian informasi mengenai diri sendiri yang dilakukan secara online di media sosial dapat memengaruhi hubungan sosial yang didapatkan secara online dan di dunia nyata. Pengungkapan diri di media sosial dinilai dapat membantu meningkatkan hubungan yang ada di dunia nyata. Hal ini disebabkan karena tidak sedikit pengguna media sosial yang saling terhubung dengan orang-orang yang dikenalnya di dunia nyata berinteraksi juga dengan mereka di media sosial (Ko \& Kou, 2009). Selain itu, pengguna media sosial yang memiliki koneksi dan kepercayaan dalam hubungan sosial di dunia nyata dapat menikmati interaksi sosial cukup luas secara online (Lee dkk., 2011).

Persepsi dukungan sosial pun terbukti memiliki pengaruh terhadap kesejahteraan subjektif. Temuan ini sesuai dengan hasil penelitian Nauffal dan Sbeity (2013), yang menunjukkan bahwa ketika individu memiliki persepsi dukungan sosial yang mencukupi maka individu tersebut dapat merasa puas dengan pengalaman kehidupannya. Tempat pertama munculnya interaksi dengan orang lain dimulai dari lingkungan terdekat, yaitu keluarga. Seiring dengan bertambahnya usia, perkembangan interaksi sosial menjadi lebih luas, terutama di masa remaja ketika individu tidak hanya melakukan interaksi dengan keluarga saja melainkan dengan lingkungan sekolah dan lingkungan sosial lainnya yang dapat memberikan berbagai dampak pada proses perkembangan (Gulacti, 2010). Singkat kata, dorongan membangun hubungan yang baik dengan keluarga ataupun teman sangat penting untuk remaja karena dapat berpengaruh pada kesejahteraan subjektif (Matsuda, Tsuda, Kim, \& Deng, 2014).

Penelitian ini menunjukkan hasil bahwa (lihat Gambar 1) persepsi dukungan sosial dapat menjadi mediator peran pengungkapan diri terhadap kesejahteraan subjektif. Temuan yang dilakukan oleh Nabi dkk. (2013) menunjukkan bahwa persepsi dukungan sosial terbukti berperan signifikan dalam dalam memediasi hubungan antara jumlah teman di media sosial dengan kesejahteraan subjektif.

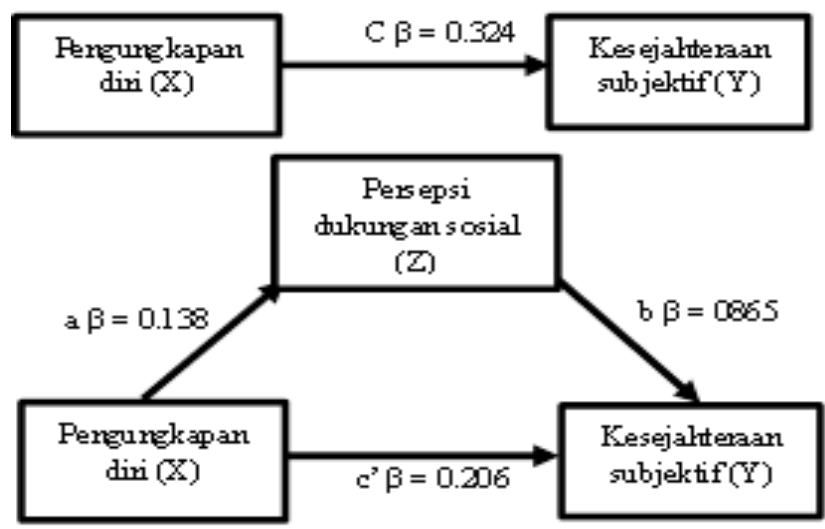

Gambar 1. Peran persepsi dukungan sosial sebagai mediator pengungkapan diri dan kesejahteraan subjektif 
Hubungan antar variabel sebagaimana ditampilkan pada Gambar 1 di atas mengandung makna bahwa ketika nilai pengungkapan diri naik satu satuan maka dapat diprediksikan bahwa kesejahteraan subjektif akan menguat juga. Selain itu, Gambar 1 juga bisa ditafsirkan bahwa pengungkapan diri berpengaruh terhadap perceived social support. Artinya, ketika nilai pengungkaan diri naik satu satuan maka dapat diprediksikan bahwa perceived social support akan menguat juga. Pengungkapan diri di media sosial dapat meningkatkan hubungan sosial di dunia nyata sehingga pengguna media sosial memiliki peluang untuk mendapatkan dukungan sosial ketika dibutuhkan. Makna terakhir dari Gambar 1 adalah perceived social support berpengaruh signifikan terhadap kesejahteraan subjektif. Artinya, ketika nilai perceived social support naik satu satuan maka dapat diprediksikan bahwa kesejahteraan subjektif akan menguat juga. Individu yang memiliki keyakinan ketersediaan dukungan sosial ketika dibutuhkan dapat memberikan kepuasan hidup dan pengalaman yang menyenangkan. Perceived social support berkontribusi dalam memediasi peran pengungkapan diri terhadap kesejahteraan subjektif. Secara lebih spesifik, perceived social support menjadi mediator dengan kategori mediasi parsial karena setelah variabel ini dimasukkan dalam persamaan regresi, peran pengungkapan diri terhadap kesejahteraan subjektif menjadi berkurang.

Berdasarkan hasil-hasil dalam penelitian ini, peneliti perlu menyampaikan sejumlah saran. Pertama, pengguna media sosial diharapkan dapat menggunakan Instagram secara bijak ketika mengunggah sesuatu, khususnya yang terkait dengan informasi pribadi untuk menghindari penyalahgunaan data. Kedua, pengguna media sosial diharapkan dapat memanfaatkan media sosial untuk membangun dan menjaga hubungan sosial baik secara online ataupun di dunia nyata, dengan tujuan untuk menjaga kualitas hubungan. Ketiga, kepada peneliti selanjutnya diharapkan dapat melakukan penelitian pada pengguna media sosial yang lain selain Instagram seperti misalnya Twitter karena setiap media sosial memiliki karakteristik tersendiri.

\section{Daftar Pustaka}

Asosiasi Penyelenggara Jasa Internet Indonesia (2017, Oktober 12). Hasil survei penetrasi dan perilaku pengguna internet Indonesia 2017. Diakses dari https://apjii.or.id/content/read/39/342/H asil-Survei-Penetrasi-dan-PerilakuPengguna-Internet-Indonesia-2017

Baron, R. M., \& Kenny, D. A. (1986). The moderator-mediator variable distinction in social psychological research: Conceptual, strategic, and statistical considerations. Journal of Personality and Social Psychology, 51, 1173. DOI: 10.1037//0022-3514.51.6.1173

Batool, F., \& Zubair, A. (2018). Role of shyness and perceived social support in self-disclosure among university students. Pakistan Journal of Psychological Research,33, 35-54. Diakses dari: http://www.pjprnip.edu.pk/pjpr/index.ph p/pjpr/article/view/432

Buhrmester, D., \& Prager, K. (1995). Patterns and functions of self-disclosure during childhood and adolescence. In K. J. Rotenberg (Ed.), Cambridge studies in social and emotional development. New York, NY, US: Cambridge University Press.

Chen, Y., Zhou, Y., Zhu, S., \& Xu, H. (2012). Detecting offensive language in social media to protect adolescent online safety. In Proceedings - 2012 ASE/IEEE International Conference on Privacy, Security, Risk and Trust and 2012 
ASE/IEEE International Conference on Social Computing, SocialCom/PASSAT 2012 (pp. 71-80). [6406271] (Proceedings - 2012 ASE/IEEE International Conference on Privacy, Security, Risk and Trust and 2012 ASE/IEEE International Conference on Social Computing, SocialCom/PASSAT 2012). https://doi.org/10.1109/SocialCo m-PASSAT.2012.55

Chu, P. S., Saucier, D. A., \& Hafner, E. (2010). Meta-analysis of the relationships between social support and well-being in children and adolescents. Journal of Social and Clinical Psychology,29, 624-645.

DOI:

10.1521/jscp.2010.29.6.624

Creswell, John W. 2012. Educational research: Planning, conducting and evaluating quantitave and qualitative research $\left(4^{\text {th }}\right.$ ed.) Boston: Pearson Education, Inc.

Diener, E. D., Emmons, R. A., Larsen, R. J., \& Griffin, S. (1985). The satisfaction with life scale. Journal of Personality Assessment, 49, 71-75. DOI: 10.1207/s15327752jpa4901_13

Diener, E., Oishi, S., \& Lucas, R. E. (2003). Personality, culture, and subjective well-being: Emotional and cognitive evaluations of life. Annual Review of Psychology, 54, 403-425. DOI: 10.1146/annurev.psych.54.101601.1450 56

Diener, E., Wirtz, D., Tov, W., Kim-Prieto, C., Choi, D. W., Oishi, S., \& BiswasDiener, R. (2009). New well-being measures: Short scales to assess flourishing and positive and negative feelings. Social Indicators Research, 97, 143-156.

https://doi.org/10.1007/s11205-0099493-y

Fauzia, A. Z., Maslihah, S., \& Ihsan, H. (2019). Pengaruh tipe kepribadian terhadap self- disclosure pada dewasa awal pengguna media sosial instagram di Kota Bandung. Journal of Psychological Science and Profession, 3(3), 151-160. https://doi.org/10.24198/jpsp.v3i3.2343 4

Gulacti, F. (2010). The effect of perceived social support on subjective well-being. Procedia Social and Behavior Sciences. 2 , 3844-3949. https://doi.org/10.1016/j.sbspro.2010.03 .602

Ko, H. C., \& Kuo, F. Y. (2009). Can blogging enhance subjective well-being through self-disclosure?. CyberPsychology \& Behavior, 12, 75-79. DOI: 10.1089/cpb.2008.016

Lee, G., Lee, J., \& Kwon, S. (2011). Use of social-networking sites and subjective well-being: A study in South Korea. Cyberpsychology, Behavior, and Social Networking, 14, 151-155. DOI: 10.1089/cyber.2009.0382

Lee, K. T., Noh, M. J., \& Koo, D. M. (2013). Lonely people are no longer lonely on social networking sites: The mediating role of self-disclosure and social support. Cyberpsychology, Behavior, and Social Networking, 16, 413-418. DOI: 10.1089/cyber.2012.0553

Mailanto, A. (2016, Januari 14). Pengguna Instagram di Indonesia terbanyak, mencapai 89. Techno.okezone.com/. Diakses dari https://techno.okezone.com/read/2016/0 1/14/207/1288332/pengguna-instagramdi-indonesia-terbanyak-mencapai-89

Matsuda, T., Tsuda, A., Kim, E., \& Deng, K. (2014). Association between perceived social support and subjective well-being among Japanese, Chinese, and Korean college students. Psychology, 5, 491499. DOI: $10.4236 /$ psych.2014.56059 
Nabi, R. L., Prestin, A., \& So, J. (2013). Facebook friends with (health) benefits? Exploring social network site use and perceptions of social support, stress, and well-being. Cyberpsychology, Behavior, and Social Networking, 16, 721-727. https://doi.org/10.1089/cyber.2012.0521

Nauffal, D. A. D., \& Sbeity, R. (2013). The role of perceived social support in predicting subjective well-being in Lebanese college students. Happiness \& WellBeing, 1, 121-134. Diakses dari https://laur.lau.edu.lb:8443/xmlui/bitstre am/handle/10725/4075/Role.pdf?sequen $\mathrm{ce}=1 \&$ isAllowed $=\mathrm{y}$

Neve, J. E., Diener, E., Tay, L., \& Xuereb, C. (2013). The objective benefits of subjective well-being. New York: UN Sustainable Development Solutions Network. Diakses dari http://eureka.sbs.ox.ac.uk/5466/1/SSRN -id2306651.pdf

Park, N. (2004). The role of subjective wellbeing in positive youth development. The Annals of the American Academy of Political and Social Science, 591, 25-39. https://doi.org/10.1177/0002716203260 078

Seligman, M. (2013). Beyond authentic happiness. Bandung: Kaifa.

Steinberg, L. (2016). Adolescence. New YorkMc: Graw-Hill Education.

Taddei, S., \& Contena, B. (2013). Privacy, trust and control: Which relationships with online self-disclosure? Computers in Human Behavior, 29, 821-826. DOI: 10.1016/j.chb.2012.11.022

Taylor, S. E., Sherman, D. K., Kim, H. S., Jarcho, J., Takagi, K., \& Dunagan, M. S. (2004). Culture and social support: Who seeks it and why?. Journal of Personality and Social Psychology, 87, 354. DOI: 10.1037/0022-3514.87.3.354
Tichon, J. G., \& Shapiro, M. (2003). The process of sharing social support in cyberspace. CyberPsychology \& Behavior, 6, 161-170. DOI: 10.1089/109493103321640356

Valkenburg, P. M., Peter, J., \& Schouten, A. P. (2006). Friend networking sites and their relationship to adolescents' wellbeing and social selfesteem. CyberPsychology \& Behavior, 9, 584-590. DOI: 10.1089/cpb.2006.9.584

Valkenburg, P. M., \& Peter, J. (2011). Online communication among adolescents: An integrated model of its attraction, opportunities, and risks. Journal of Adolescent Health, 48, 121-127. DOI: 10.1016/j.jadohealth.2010.08.020

Walrave, M., Vanwesenbeeck, I., \& Heirman, W. (2012). Connecting and protecting? Comparing predictors of self-disclosure and privacy settings use between adolescents and adults. Cyberpsychology: Journal of Psychosocial Research on Cyberspace, 6, 1-16. https://doi.org/10.5817/CP2012-1-3

Wang, G., Zhang, W., Chen, Q., \& Zeng, R. (2018). How is negative affect associated with life satisfaction? The moderating role of online self-disclosure in China's context. Personality and Individual Differences, 135, 60-66. https://doi.org/10.1016/j.paid.2018.07.0 02

Wei, S., Zou, H., Wang, J. (2018). The relationship between college students self-disclosure online and loneliness, social support as mediation. Global Journal of Advanced Research, 5, 8794.

Diakses

dari: http://www.gjar.org/publishpaper/vol5is sue3/d800r71.pdf 
Wheeless, L. R. (1978). A follow-up study of the relationships among trust, disclosure, and interpersonal solidarity. Human Communication Research, 4, 143-157. https://doi.org/10.1111/j.14682958.1978.tb00604.x

Yusoff, Y. M. (2012). Self-efficacy, perceived social support, and psychological adjustment in international undergraduate students in a public higher education institution in Malaysia. Journal of Studies in International Education, 16, 353-371. https://doi.org/10.1177/1028315311408 914

Zimet, G. D., Dahlem, N. W., Zimet, S. G., \& Farley, G. K. (1988). The multidimensional scale of perceived social support. Journal of Personality Assessment, 52, 30-41. DOI: 10.1207/s15327752jpa5201_2 